\title{
COMPUTERISED SOFTWARE SYSTEMS IN REPLACEMENT MAINTENANCE INFORMATION MANAGEMENT: A SOUTH AFRICAN CASE STUDY
}

\author{
P.A. Ozor ${ }^{1,2 *}$, E.N. Nwobodo-Anyadiegwu ${ }^{1} \&$ C. Mbohwa ${ }^{1}$
}

\section{ARTICLE INFO}

\section{Article details}

Presented at the $31^{\text {st }}$ annual conference of the Southern African Institute for Industrial Engineering (SAllE), held virtually from 5-7 October 2020 .

Available online $\quad 11$ Nov 2020

\section{Contact details}

* Corresponding author p.ozor@uj.ac.za

Author affiliations

1 Department of Quality and Operations Management, Faculty of Engineering and the Built Environment, University of Johannesburg, South Africa

2 Department of Mechanical Engineering, University of Nigeria, Nsukka, Nigeria

\section{ORCID ${ }^{\circledR}$ identifier}

P.A. Ozor

https: / /orcid.org/0000-0003-4301-2696

E.N. Nwobodo-Anyadiegwu

https://orcid.org/0000-0001-8051-9459

C. Mbohwa

https://orcid.org/0000-0002-8268-5984

DOI

http://dx.doi.org/10.7166/31-3-2420

\section{ABSTRACT}

Computerised software systems have undeniably continued to gain recognition in the implementation of reliable maintenance policies in today's Industries. While significant investigations corroborating the importance of management technology in developed economies abound, this study examines the level of the technology's success in a typical manufacturing firm in South Africa. Using an analytical research approach, useful maintenance indices were established from the dataset stored in the maintenance information management system of a case example manufacturing firm, designated ' $X$-Company' in this research for the sake of confidentiality. The result shows that, as applied currently to the replacement maintenance of the case example system, the technology requires optimisation. Maintenance policies that can improve the poor correlation between the current status on the one hand, and the established trends in the maintenance engineering literature and practice on the other, are recommended.

\section{OPSOMMING}

Gerekenariseerde sagtewarestelsels speel 'n toenemende rol in die implementering van betroubare instandhoudingsbeleid in die moderne industrie. Daar is veelvuldige ondersoeke wat die belangrikheid van bestuurstegnologie in ontwikkelde ekonomieë bevestig, maar hierdie studie ondersoek die vlak van die tegnologie se sukses in 'n tipiese vervaardigingsfirma in Suid-Afrika. Nuttige instandhoudingsindikators is deur ' $n$ analitiese navorsingsbenadering opgerig vanuit ' $n$ datastel van ' $n$ vervaardigingsfirma, aangedui as 'Maatskappy $X$ ' in dié artikel om vertroulikheid te handhaaf. Die resultaat toon dat die huidige implementering van die vervanging instandhouding gevallestudie verbeter kan word. Instandhoudingsbeleid wat die swak korrelasie tussen die huidige toestand, die gevestigde neigings in die literatuur en die praktyk, word voorgestel.

\section{INTRODUCTION}

Computerised software systems and programs have continued to gain significant recognition in the implementation of reliable maintenance policies in today's industries. Some authors suggest that this technology can store maintenance operations data sets on which to base calculations and projections to make decisions about optimal maintenance [1]-[3]. Change management has been advocated as important to the successful implementation of these systems, of which the computerised maintenance management system (CMMS) is a typical example. The development of the CMMS has been an 'open sesame' to very effective maintenance management technologies [4]. The procedure of the CMMS derives much of its support from quality information management. Therefore the poor management of information can entirely defeat the purpose of using the technology. In its design, CMMS software offers tools that are required to implement a whole maintenance management programme for a repairable system. CMMS systems can track equipment information, determine reliability, and construct forecasting based on the information captured in the system, in addition to having the ability to clear bottlenecks [5]. Manufacturing companies are among the most maintenance-intensive outfits in the production of goods and services. Whether the focus is on the creation of goods or on providing services, various repairable systems are used in conjunction with man 
and materials [6]. Lopez-Campos and Marquez [1] report that organisations frequently make investments that can guarantee continuous preventative and predictive maintenance. There seems to be a generalised trend among maintenance researchers of developing strategies that can keep the manufacturing company's equipment and facilities running at some optimal level [7]. The features of careful information management through informed holistic data-gathering and proper record-keeping, which in the long run can guarantee the effective control of all aspects of maintenance function, has been discussed with very little attention, if considered at all, in the literature. Through the full implementation of CMMS in maintenance tracking, the future recurrence of failures can be curtailed, if not prevented. The whole maintenance function can be integrated into policy-making and optimal performance strategy designs, with a resulting improvement in the productivity of the organisation. The insufficiency of CMMS application in manufacturing firms has been observed, and the need to up the ante is well documented [8]-[9]. While the partial or low adoption of the CMMS technology is still reported in the recent literature [2], [9]. Wienker et al. [2] specifically observe that the lack of successful implementation still presents a dismal picture.

Generally speaking, accurate maintenance information-gathering and storage can enhance the overall management of maintenance activities, particularly in manufacturing industries. If such information is processed into data and carefully analysed, a streamlined maintenance function can be achieved - for instance, proper and robust decisions on preventive maintenance scheduling, cost-effective replacement policies, evaluation of actual life against the design life of components, appraisal of maintenance performances to prevent deviations early on and to sustain desired trends. However, manufacturing companies in some developing countries can hardly boast of incorporating the standard CMMS approach. While the conversations on the full capabilities of CMMS in the literature are extensive, at least from the point of view of the authors cited in this study, there are still obvious research gaps on the status and performance of the technique in South African industries. To ascertain the precise level of interest in CMMS in an emerging economy such as South Africa, a total reliance on reports in the literature definitely does not suffice. More research is required to guarantee a complete delineation of the actual status with a view to effecting improvements. Maintaining country, regional, industry, or system specificity can offer more accurate results for effective CMMS-based maintenance policies. In this paper, we attempt to assess the level of successful CMMS integration and implementation in relation to information management of the maintenance function, using the case study of a manufacturing industry in the Mpumalanga province of South Africa. The authors are not aware of any similar work in the literature.

\section{GLOBAL INTEGRATION OF THE CMMS TOOL IN MAINTENANCE}

The CMMS technology has widely been accepted as a suitable technique for optimising the profitability of maintenance of an organisation [10]-[12]. Past researchers agree that it is a powerful tool for gathering and managing maintenance information [2], [13], [14]. As a maintenance optimisation support tool, CMMS can also provide a tangible basis for decisions about alternatives, thereby enhancing the administration of the maintenance function [15]. When the technology is well-structured, appropriate records on the performance, state of health, and remaining useful life of manufacturing systems can be known with greater precision. The application of the technology in the data management of almost every organisational sphere to execute a computerised information system properly has recently been canvassed, even though the usual resistance of employees to change was feared as a possible hindrance [16]. The basic subdivisions of a CMMS plan are already documented [17]. The authors specifically point out that the efficacy of the tool in the data analytics aspect of maintenance can transform the mode of planned and unplanned maintenance interventions. The overarching culture of dependence in fixing damaged parts and just managing to keep the equipment running, as practised in manufacturing companies, especially in developing countries, could be a thing of the past if CMMS were embraced. The major disadvantage of relying on the older technique is that maintenance costs and equipment performance indices are indiscriminate and are rarely documented. On the other hand, CMMS plays the significant role of providing evidential knowledge that can be generated from the system for the purpose of supporting the selected maintenance strategy [18]. The authors further explain that the technology can highlight input-output relationships, the appropriate data to be captured, the required maintenance structures, and the workflow processes to be supported by management. Elsewhere, Parida et al. [19] discuss the use of CMMS in job ordering and employee scheduling. Labour utilisation rates and task assignments are also possible with a proper implementation of the technology, according to the authors. Other researchers, such as Wienker et al. [2] and Mandal and Tewari [20], have described the use of CMMS technology in achieving and stabilising improved availability as well as attaining cost-effective system maintainability. Improved availability and maintainability can generally result in reduced manufacturing costs [20]-[23]. Thus the ability of CMMS to delineate salient maintenance-related information about systems, subsystems, and components, or even units, can be harnessed to ensure that all cost-incurring practices are curbed in good time. 


\subsection{Overview of CMMS application in maintenance management}

The CMMS principle has received attention in various facets of the maintenance field. Most of the literature reports are geared to improving productivity by using the information and data analytic capabilities to increase up-time and decrease cost. Other areas that are worth mentioning include condition, equipment health and performance, and workload monitoring. For instance, Azahar and Mydin [24] investigate the implementation of CMMS in monitoring completed projects in the construction industry as part of exploring its benefits, capabilities, and different modes. In particular, the tool was introduced as a predesign standalone technique for improving the maintainability of buildings only, without regard to information monitoring. On the other hand, Mohammadfam [25] discusses the use of CMMS as a post-performance evaluation package, and maintains that the tool can be employed in appraising the extent of the realisation of the organisation's key performance indices (KPI) - notably, the mean time to repair (MTTR) and the mean time between failures (MTBF). There is a good publication that is dedicated to the effort of KPI measurement [15]. The full application of CMMS technology in the maintenance management and organisation of power plants is available [20], [26]. The studies are concerned mainly with maintenance policy prescription frameworks and the progressive development of CMMS through the use of analytical algorithms. The authors also show how CMMS can be developed successfully to separate breakdowns and scheduled job orders, although the models were not validated on any real-world data, as information management was conspicuously missing in the two presentations.

A typical reference point for CMMS application in manufacturing industries is presented in Jamkhaneh et al. [10]. The work is very interesting, particularly for its explanation of how CMMS can be applied to total productive maintenance (TPM), with over 60 manufacturing companies being considered. There are other notable and excellent presentations on CMMS use in manufacturing and allied company maintenance activities in the literature [2], [27]-[29]. Apart from chronicling the efforts made in applying CMMS to maintenance planning, the geographical spread of those publications and examples provide handy material for researchers who are interested in the proper information management of maintenance systems.

The proper handling of the intertwined management of process knowledge and information can have a key role in determining the possible outcomes of a maintenance programme [16]. A full understanding of the process required in a selected maintenance policy can rapidly enhance timely decision-making. To achieve this, the collaborative maintenance planning system (COMPS) has been proposed to bridge the information gap between an organisation's upstream and downstream hierarchies [17]. The COMPS approach is intended to smooth the information reporting structure in the organisation, and not necessarily delve into the information contained in the CMMS scheme in the in-house maintenance management. Interested readers can refer to data collection and information management reports, especially in outsourced maintenance [30].

Also worthy of mention is the so-called computerised maintenance management for information systems (CMMIS) of Arha and Yadav [6], which stresses the efficient and effective use of available resources to achieve low costs. Good management of maintenance information can result in improved quality and more profitable operations for an organisation, especially when matters are simplified by applying CMMS techniques. The tool can speed up the proper documentation of industrial facilities and their management, ranging from the reduction of the cost of maintenance operations to the increased satisfaction of the facility users' expectations [31]. Specialised computerised software systems have emerged to improve the functions of facility managers, such as the building information management system (BIMS), which relies on human input to develop detailed information about maintenance operations. The BIMS, which was originally based on the principles of CMMS, can enhance the flexible handling of maintenance information, thereby increasing the robustness and efficacy of that information. The importance of the articulate management of information in various maintenance schemes cannot be over-emphasised [32]. In a condition monitoring programme, for instance, CMMS can retrieve diagnostic data and offer prognostic ideas using special sensors. With such data in place, a design out maintenance policy (DOM) can be implemented. The DOM is essentially targeted at the continuous improvement of maintainable equipment and the system of conducting maintenance. The DOM technique can be achieved by redesigning or eliminating the system completely, since its focus is on instituting economic maintenance systems for both personal and the maintenance operator. Research efforts in DOM are still very scanty, probably owing to the exhaustive amount of training, knowledge, and experience required for its successful implementation.

The CMMS has been applied to ergonomic factor considerations in maintenance schemes, particularly human error that affects the optimal performance of maintenance [33]. Technically speaking, the state or mood of the maintenance crew can affect their performance of maintenance actions by influencing the decisions of the workers to the extent of recording inaccurate information. The CMMS alternative avoids such errors 
by using accurate techniques of data-gathering and development to arrive at the best course of maintenance action [34]. However, more research needs to be conducted in this area because the maintenance decision analytic capability ought to be augmented by a process that can ensure the information's validity. As presented in most of the literature cited above, correct answers to the question of how best to incorporate CMMS into the improved accuracy of maintenance information are not yet in sight. In particular, many of the authors have raised issues about data-collection and decision-making techniques. Others focus on the development of CMMS, its performance and actual implementation, and its specifications. Figure 1 presents the number of companies and the focus areas in the reviewed works.

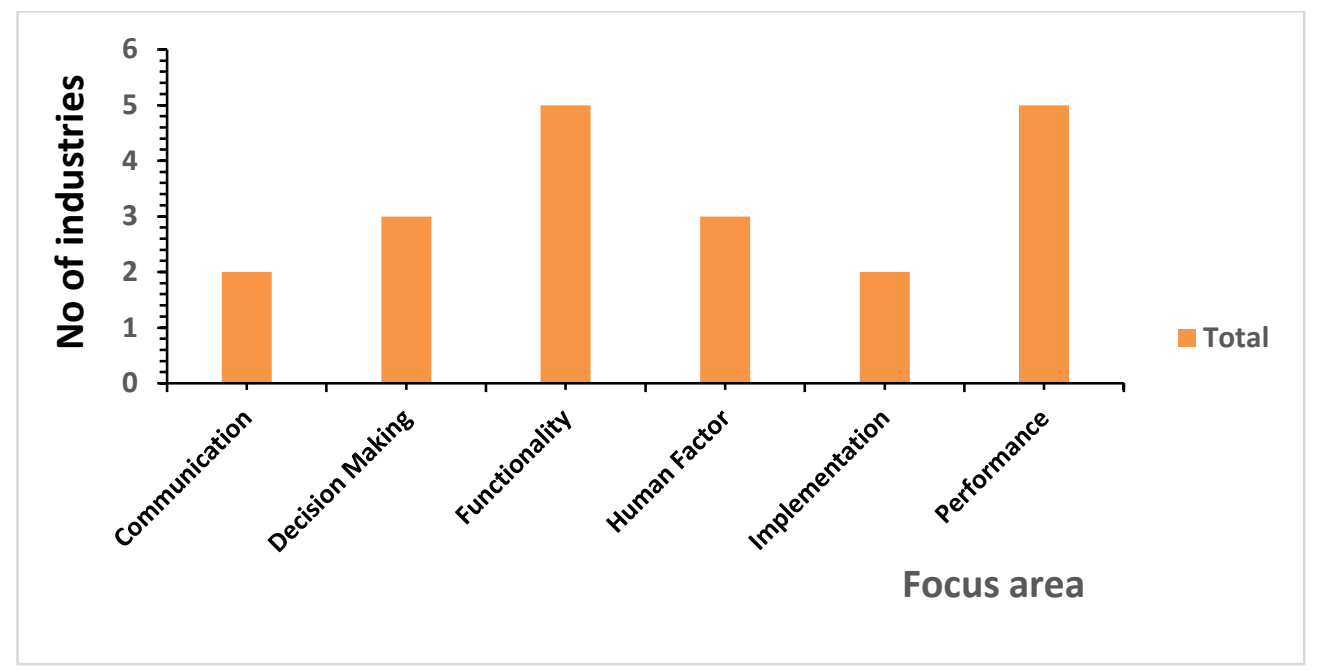

Figure 1: Literature on number of industries and focus areas

\section{MATERIALS AND METHODS}

This study employed an analytical research methodology, since the underlying thrust was to examine the usefulness of integrating CMMS into the maintenance information management of a manufacturing firm in South Africa.

The manufacturing company in this case study is called ' $X$ Company' to preserve confidentiality. It is located in Mpumalanga province. The company's main business is to manufacture original equipment for construction and allied firms. It also outsources maintenance services to various mines in Mpumalanga.

Particular equipment was selected for the research pilot study to assess whether or not X Company was using the CMMS effectively as a tool for information management in their maintenance activities. The equipment was available and on contract at the time of the data collection. The chosen machine consisted of a number of components that have different life expectancies. Based on the contract between the company and the mines, the replacement of a failing or failed component was expected to be implemented in the month before the design life month. The reason for adopting this policy was to avoid costly unplanned maintenance in ensuring the desired performance of the equipment.

The data was collected from the CMMS that was currently being used in the company. The data used was considered suitable and valid for the analysis because it was retrieved from a live CMMS. The information retrieved was independent, as it was controlled by the strategy tasks, which are automated for reliability. The results were based on an analysis of the historical data of components' replacement and ordering, to determine the reliability, availability, and maintainability of the selected system.

Mainly secondary data sources were used to obtain a better view of the constitutive variables that needed to be specified, although on-site CMMS data was also sourced from the equipment being studied while it was in operation. In implementing the study, both online articles and those published in high-quality peerreviewed journals and some conference proceedings were relied on to determine the global status of CMMS's incorporation in maintenance information management. Thereafter interviews were organised with the management of ' $X$ Company', especially those charged with managing the maintenance function who had worked for at least the five years from 2014 to 2018 - the period of the study. This period represented 
the time when the CMMS was being experimented with in the company. The aim of the interviews was to obtain information on the existing maintenance culture and equipment performance history, and to arrange for access to the historical data of the selected repairable system. The requested access was granted.

\section{ANALYSIS}

During the survey of the company's maintenance personnel, it was suggested that the data on equipment replacement maintenance be used as a representative dataset to study the CMMS information's accuracy. This was informed by the level of care given to the inventory management of the company, which had some intermediaries of quality control. It would have been difficult to take a part from the store without its being accurately captured by the relevant computers. While the inventory data was not directly needed for the study, the equipment failure and repair history was of great relevance, and so was specifically sought. As presented in the literature [21], corrective maintenance can result from two important modes of failure: critical or non-critical. The replacement data was sorted accordingly - that is, parts that were replaced on-line or within a very short time were treated as non-critical replacements. It was discovered that some components in this group had redundant pairs that could be used in case of an emergency. So their repair times were comparatively insignificant. The ones that required the normal operation of the equipment to be stopped, at times owing to multiple failures, were regarded as critical replacements. In the end, the data of the latter played a greater role in the study because the analysis of them yielded precise values for the metrics needed to characterise the replacement operation. Accordingly, questions about the performance history of the case equipment were asked, and the answers were provided via the release of the CMMS stored data. It was possible to access the system failure date, failure time, repair start date and time, repair end date and time, and reasons for failure. The reasons for failure made the evaluation of the failure mode (the exact failed point/part) and cause (what really happened) possible, and was combined with the time-to-repair to make it easier to sort the individual replacements as either critical or non-critical. The calculated repair and failure times were ranked in ascending order. Then descriptive statistics and standard models were applied to deduce other important parameters. In particular, these useful maintenance indices for the total uptime and the number of breakdowns, as well as the total amount of downtime, were established from the equipment failure-and-repair history and used for further analysis. The results are shown in Figures 3 to 5. The literature [22], [35] presents models (1) to (3) to determine system availability, the mean time to repair (MTTR), and the mean time between failures (MTBF).

$$
\begin{aligned}
\text { Availability } & =\frac{\text { Total Uptime }}{(\text { Total uptime }+ \text { Total downtime })} \\
M T T R & =\frac{\text { Total downtime }}{\text { Number of Breakdowns }} \\
M T B F & =\frac{\text { Total uptime }}{\text { Number of Breakdowns }}
\end{aligned}
$$

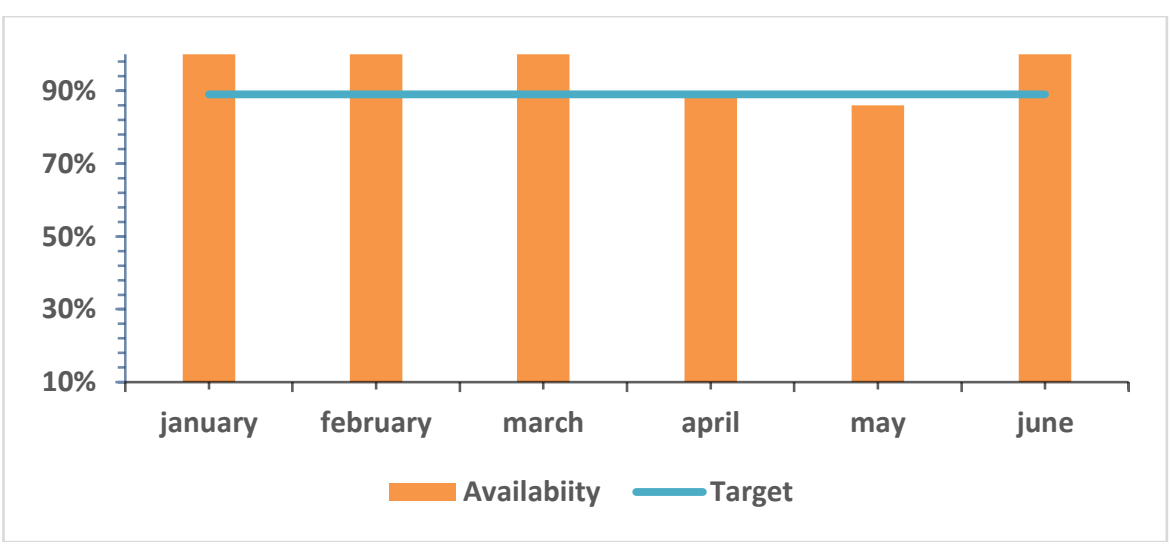

Figure 2: Maintenance history 


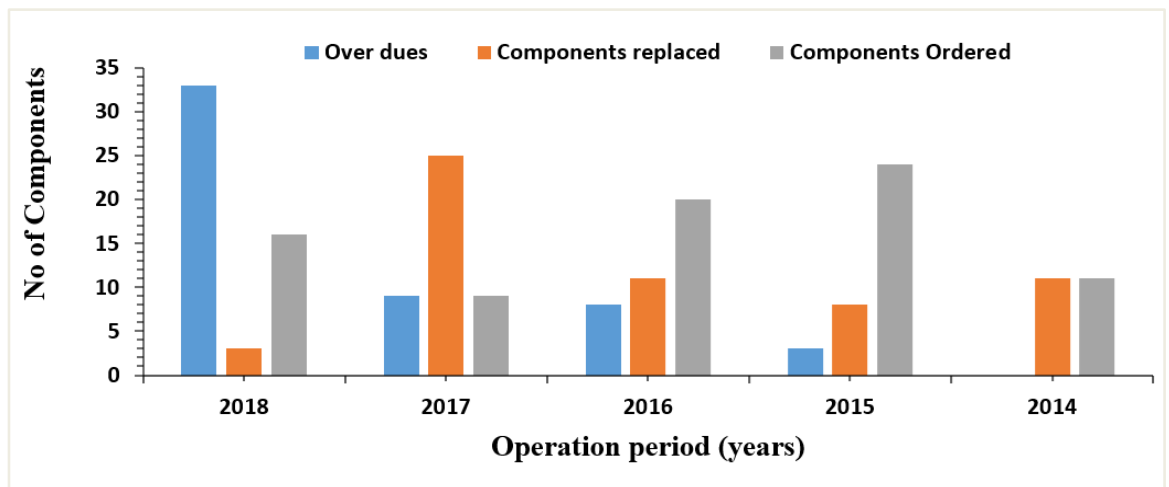

Figure 3: Equipment availability

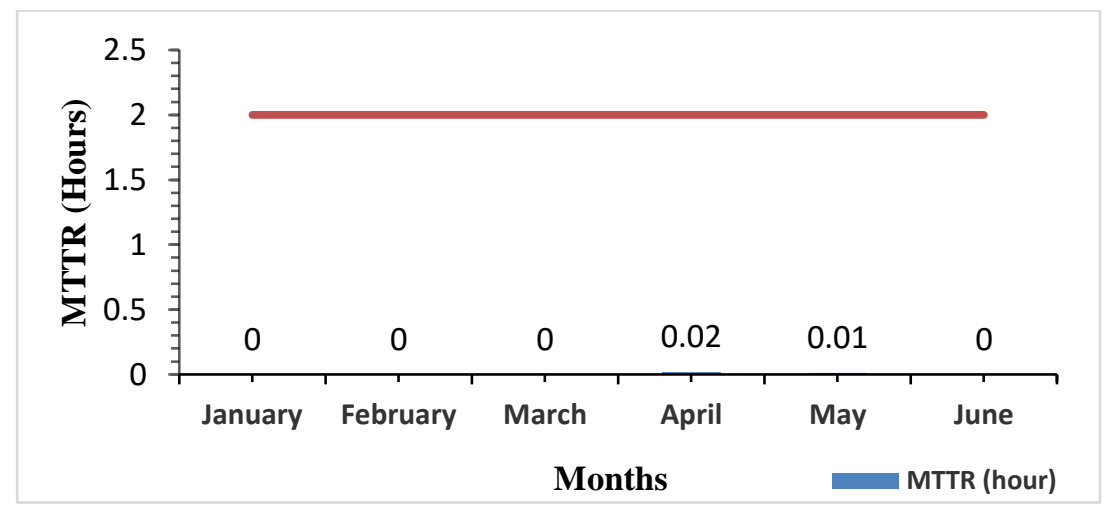

Figure 4: Equipment mean time to repair

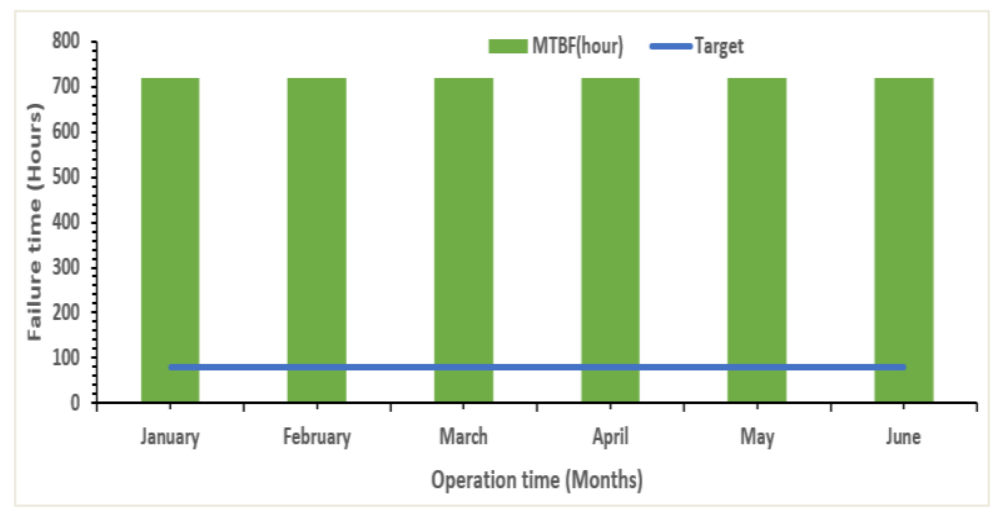

Figure 5: Mean time between failures

\section{RESULTS AND DISCUSSION}

From the results of the analysis captured in Figures 2 to 5 it can be seen that a CMMS-informed maintenance management system can be useful in understanding both the immediate and the remote state of an identified repairable system. Thus the replacement data presented in Figure 2 is both valid and useful for accurate analysis. The details in Figure 2 were individually abstracted from the CMMS currently in use in the organisation. As a tool for the information management proposed in this study, the data was statistically analysed and presented in a form that could be reasonably and usefully applied by field technicians, whose level of academic knowledge might not permit them to interpret the CMMS's recorded information. The technicians fared well with the transformed data on a pilot test conducted after the study.

'Availability' is normally taken to mean the probability that a system is in an operational state and is performing its intended functions; and this can be expressed as a fraction of the equipment's working time. 
Figure 2 presents the averaged information on availability. It can be seen that the equipment was in optimal condition for most of the period in the study period, though it fell to about $89 \%$ and $86 \%$ in April and May respectively. The MTTR can provide information on the system's maintainability. The maintainability function determines the period in which a certain failed system can be restored to its operational state. Incidentally, there were no failures from January to March or in June in the example in Figure 4. Minor failures were recorded in April and May from the standpoint of maintainability. It took only 0.02 hours and 0.01 hours to correct the failures in April and May respectively. The MTBF is a very important quantity that can be used to determine system reliability. A very high reliability system is expected to experience wide MTBFs, in contrast to low reliability equipment that frequently presents faults and narrow MTBFs. The case study system revealed very high reliability, to the extent of surpassing the expected maintenance periods, as evidenced in Figure 5, which leads to the conclusion that the equipment runs for close to one month without experiencing any failures. However, care should be exercised in quoting this study to that effect. It must be mentioned that the equipment completed most of its assigned tasks in almost every instance of engagement without an online need for replacement. This could be the reason for having a steady state target, which in most cases was met and surpassed by the equipment. The replacement maintenance applied in Figure 1 was mainly conducted while the equipment was redundant; thus its toll on availability is not shown. Neighbourhood replacement maintenance - that is, replacement of those parts thought to fail soon - might also have contributed to the high task availability of the equipment. The real situation can be seen when the system maintenance is considered as a whole - assuming that the CMMS that gave the data was properly used. To investigate this result in further studies, we recommend integrating all kinds of maintenance into the analysis, as the replacement aspect considered in this study might have been limited in not revealing the intricacies of the equipment's performance, which could be obtained by a holistic analysis of the maintenance actions performed on the system, irrespective of their type. Of course, the quality control of the CMMS application must be tested for accuracy to ensure that there are no issues with the data.

\subsection{CMMS prospects in the case study system}

In the case study, $X$ Company signed a contract with the mine that guarantees the replacement of every overdue component during the month before the month in which it is due to be replaced. If this aspect of the contract has been duly respected, and the results as analysed still show some inexplicable issues - for example, the noticeable bias in the number of replaced components and a confusing MTBF result - then the use of the CMMS technology by the company has not yielded the desired result. It is clear that the results present a great deal of information about the monthly scheduled hours and the uptime. Some aspect of the time is not accounted for, which can also contribute to the concerning unity value of the system's availability. Apart from the instances explained in the preceding paragraph, it is impossible to obtain a unit availability. Even in such cases, the CMMS personnel should be able to capture what has happened. Overall, in our considered opinion, the CMMS as applied currently to the replacement maintenance of the case study system in particular, and to X Company in general, requires optimisation. The correlation between the CMMS information and the established trends in the maintenance engineering literature and in practice is very poor, from the results of this study.

\section{CONCLUSION}

The prospects for using computerised software systems in replacement maintenance information management in South Africa were investigated. The methodology was clearly delineated. The success level of the computerised maintenance management system in the studied case was not sufficient, from the standpoint of this study.

\section{REFERENCES}

[1] Lopez-Campos, M.A., Marquez, A.C. \& Fernandez, J.F.G. 2018. The integration of open reliability, maintenance, and condition monitoring management systems. In book: Advanced maintenance modelling for asset management (pp. 43-78). Cham: Springer.

[2] Wienker, M., Henderson, K. \& Volkerts, J. 2016. The CMMS an essential tool for world class maintenance. Procedia Engineering, 138, pp. 413-420.

[3] Ding, S.H. \& Kamaruddin, S. 2015. Maintenance policy optimization - Literature review and directions. The International Journal of Advanced Manufacturing Technology, 76(5-8), pp. 1263-1283.

[4] Jonsson, K., Mathiassen, L. \& Holmström, J. 2018. Representation and mediation in digitalized work: Evidence from maintenance of mining machinery. Journal of Information Technology, 33, pp.216-232.

[5] Campbell, J.D., Jardine, A.K. \& McGlynn, J. (eds). 2016. Asset management excellence: Optimizing equipment life-cycle decisions. Boca Raton: CRC Press. 
[6] Arha, H., Yadav, P., Singhwal, A., Saini, N. \& Tewari, P.C. 2015. Development of computerized maintenance management information system for Rico Industries, Gurgaon. IUP Journal of Mechanical Engineering, 8, (1), pp. 54-62.

[7] Wang, H.Z. \& Pham, H. 2006. Reliability and optimal maintenance. London: Springer-Verlag.

[8] Hoang, A., Do, P. \& lung, B. 2017. Energy efficiency performance-based prognostics for aided maintenance decision-making: Application to a manufacturing platform. Journal of Cleaner Production, 142, pp. 2838-2857.

[9] Marquez, A.C., Diaz, V.G.P. \& Fernandez, J.F.G. 2018. Advanced maintenance modelling for asset management, Techniques and Methods for Complex Industrial Systems, Springer International Publishing AG, (pp. 455-467), (eBook) DOI 10.1007/978-3-319-58045-6.

[10] Jamkhaneh, B., Khazaei Pool, J., Khaksar, S.M.S., Arabzad, S.M. \& Verij Kazemi, R. 2018. Impacts of CMMS and relevant supportive organizational factors on total productive maintenance. Benchmarking: An International Journal, 25(7), pp. 2230-2247.

[11] Bagadia, K. 10 keys to successful CMMS implementation. Available from: http: //WwW.reliableplant.com/read/28838/computerized maintenance management system-implementation-keys. [Accessed 24 May 2018].

[12] Hamilton, J. 2015. Early-stage transition to predictive maintenance: Using CMMS, IR scans, and vibration analysis to improve uptime and lower maintenance costs. Honours thesis, Portland State University.

[13] Duffuaa, S.O. \& Raouf, A. 2015. Computerized maintenance management systems. In Planning and control of maintenance systems (pp. 223-243). Cham: Springer.

[14] Laudon, K.C. \& Laudon, J.P. 2011. Management Information Systems (12th ed.), Upper Saddle River, NJ: Prentice Hall

[15] Oliveira, M., Lopes, I. \& Rodrigues, C. 2016. Use of maintenance performance indicators by companies of the industrial hub of Manaus. Procedia CIRP, 52, pp. 157-160.

[16] Evans, N. \& Price, J. 2018. Death by a thousand cuts: behaviour and attitudes that inhibit enterprise information asset management. Information Research, 23(1), paper 779.

[17] Wan, S., Li, D., Gao, J., Roy, R. \& Tong, Y. 2017. Process and knowledge management in a collaborative maintenance planning system for high value machine tools. Computers in Industry, 84, pp. 14-24.

[18] Ricci, F., Rokach, L. \& Shapira, B. 2015. Recommender systems: Introduction and challenges. In: Recommender systems handbook, Boston, MA: Springer, pp. 1-34.

[19] Parida, A., Kumar, U., Galar, D. \& Stenström, C. 2015. Performance measurement and management for maintenance: A literature review. Journal of Quality in Maintenance Engineering, 21(1), pp. 2-33.

[20] Mandal, S. \& Tewari, P.C. 2017. A proposed framework for CMMS for a power plant. IUP Journal of Mechanical Engineering, 10(2), pp. 62-67.

[21] Ozor, P.A. 2020. Empirical and distribution approaches for analysing reliability and maintainability of radial compressors in oil and gas systems. Procedia Manufacturing, 43, pp. 696-703. DOI: 10.1016/j.promfg.2020.02.119

[22] Ozor, P.A \& Mbohwa, C. 2018. Availability analysis of oil production systems. In Proceedings of the International Conference on Industrial Engineering and Operations Management, Pretoria / Johannesburg, South Africa, October 29 - November 1, pp. 1281-1289.

[23] Smith, D.J. 2017. Reliability, maintainability, and risk: Practical methods for engineers. Oxford: ButterworthHeinemann.

[24] Azahar, N.F. \& Mydin, M.A.O. 2014. Potential of CMMS in facilities management. AUEMR, 21(1), pp. 51-59.

[25] Mohammadfam, I., Bahmani, F. \& Mahmoudi, S. 2015. Evaluation of the implementation of a CMMS on the maintenance and safety KPIs. International Journal of Occupational Hygiene, 6(2), pp. 96-100.

[26] Pajak, M. 2015. Genetic-fuzzy system of power units maintenance schedules generation. Journal of Intelligent \& Fuzzy Systems, 28(4), pp. 1577-1589.

[27] Madhikermi, M., Kubler, S., Robert, J., Buda, A. \& Framling, K. 2016. Data quality assessment of maintenance reporting procedures. Expert Systems with Applications, 63, pp. 145-164.

[28] Lopes, I., Senra, P., Vilarinho, S., Sá, V., Teixeira, C., Lopes, J., Alves, A., Oliveira, J.A. \& Figueiredo, M. 2016. Requirements specification of a computerized maintenance management system - A case study. Procedia CIRP, 52, pp. 268-273.

[29] Ghani, A.B., Ahmad, A.F., Muhammad, A., Dan, N.S. \& Jenal, R.M. 2017. Maintenance and physical asset management issues in project commissioning. Malaysian Journal of Applied Sciences, 2(2), pp. 10-28.

[30] Murthy, D.N.P., Karim, M.R. \& Ahmadi, A. 2015. Data management in maintenance outsourcing. Reliability Engineering \& System Safety, 142, pp. 100-110.

[31] Nakama, Y., Onishi, Y. \& Iki, K. 2015. Development of building information management system using BIM toward strategic building operation and maintenance. In Proceedings of the 20th Conference on Computer-Aided Design Research in Hong Kong, Asia, pp. 397-406.

[32] Chau, H.K., Li, R.C., Lee, T.S., Cheung, B.S. \& Loy, T.S. 2015. Implementation of CMMS in upgraded pillar point sewage treatment works. Engineering asset management - Systems, professional practices and certification (pp. 889-900). Cham: Springer.

[33] Nkosi M.S. 2014. A study into the effect of human error on substandard maintenance performance and the formulation of a complete solution based on the experience of a successful maintenance organization. Unpublished M.Phil. (Mechanical Engineering) thesis, University of Johannesburg. Available from: http//ujdigspace.uj.ac.za. Accessed: 21 June 2018.

[34] Rastegari, A. \& Mobin, M. 2016. Maintenance decision making, supported by computerized maintenance management system. In 2016 Annual Reliability and Maintainability Symposium (RAMS) (pp. 1-8), IEEE.

[35] Ebeling, C.E. 1997. An introduction to reliability and maintainability engineering (International ed.). New Delhi: Tata McGraw-Hill Book Company Inc. 